способи будування споруд, адаптованих до природи та потреб людини передовими дослідницькими, конструкторськими та технологічними методами 3 метою створення стійкого архітектурного середовища.

\title{
ЛІТЕРАТУРА
}

1. Foster+Partners/Jaffe House (Skybreak House) UK 1965-1966. URL: http://www.fosterandpartners.com / projects/jaffe-house- (skybreak-house)/

2. Наше спільне майбутнє - Доповідь Всесвітньої комісії 3 питань навколишнього середовища і розвитку. URL: http://www.un.org/ru/ga/pdf/brundtland.pdf

3. Оцінка стійкості студентських проектів в навчальному процесі Московського архітектурного інституту (Державна академія). Вебінар МАРХИ - АВОК, 20 травня 2015 р. http://webinar.abok.ru/webinar/marhi-2015/

4. Есаулов Г. В. Стійка архітектура як проектна парадигма (до питання визначення) // Стійка архітектура: сьогодення і майбутнє: тр. міжнар. симпозіуму, 17-18 листопада 2011 р. М., 2012. С. 76-79. (Наук. тр. Моск. арх. ін-ту (держ. академії) і групи КНАУФ СНД).

5. Есаулов Г. В. Стійка архітектура - від принципів до стратегії розвитку // Вісник ТГАСУ. 2014. № 6. С. 9-23.

6. Досвід країн Євросоюзу 3 підвищення енергоефективності, енергоаудиту та енергоменеджменту 3 енергоощадності в економіці країн. URL: https://ua.energy/wpcontent/uploads/2018/01/Pidvyshhennya-energoefektyvnosti-v-YES.pdf

7. https://www.architravel.com/architravel/building/david-l-lawrence-convention-center/

8. https://www.stefanoboeriarchitetti.net/en/vertical-forest-en/ateliers-jean-nouvel-one-centralpark-sydney/

9. https://www.archdaily.com/880371/sino-italian-ecological-and-energy-efficient-building-mariocucinella-architects

doi: $10.31650 / 2519-4208-2020-20-18-27$

\section{CURRENT STATE AND PROSPECTS OF DEVELOPMENT OF THE COASTAL AREA OF ODESSA}

O. Savitskaya, associate professor of the Department of Urban Planning e-mail: olgasavgrad@gmail.com; ORCID: orcid.org/0000-0003-0362-2502

O. Vasylenko, doctor of architecture, professor, Department of architect design e-mail: abvasilenko10@gmail.com; ORCID:0000-0002-8261-3104

Odessa State Academy of Civil Engineering and Architecture

Annotation: This article is a response to the urgent problem of the development and use of the coastal territories of Odessa. Based on the analysis of the historical, social, urban planning and economic context, the article argues the landscape and recreational direction of the development of coastal territories. In addition, the principles, main stages and methods for the formation and maintenance of this territory on a scale from improvement to the urban development role in the city system have been identified. The analysis of trends and problems of sustainable urban development. In creating a -sustainable\| urban environment, the role of various specialists is extremely important: urban planners, architects, ecologists, and -urbanisms\| of various -urban\| specialties. Only by methods of an integrated approach is it possible to create a full-fledged space, interconnected with nature, historical and cultural monuments. 
With a good location relative to the city, Odessa slopes are not balanced in function and in intensity of operation, which leads to their inefficient use and economic loss of the territory. The analysis revealed a complex of accumulated problems. These are administrative-political, socialfunctional, economic,ecological, cultural.

The article proposes an Accession Program promoting park protection - attracting political and public organizations, as well as possible formats for attracting investments. All this is formed under the condition of: - complete conservation of green areas; point inclusion of improvement in the structure of the park; improvement of roads and trails; the formation of places of various saturation and functionality; conservation of the -wild\| park.

The concept of coastal development is unambiguously a landscape-recreational zone. This determines the maximum recreation, development, improvement of the natural complex; minimization and localization of urbanized areas; withdrawal from the zone of automobile transport; the organization of convenient, aesthetically and environmentally friendly communications of the city with the coast, taking into account all the visual points of disclosure, both on the sea and on the marine facade; organization of water public transport

The article proposes one of the options for the development of the Odessa coast - the formation of urban planning axes of the city - the sea. The result is a convenient communication city - park - beach - sea in the form of stairs, ramps, escalators and other ways of vertical communication between the upper and lower plateaus. On the upper plateau, architectural town-planning ensembles of various functional purposes are formed. An expressive silhouette of the city is created. the territory of the slopes, their connection.

The coastal zone is decided in the format of a fully accessible shore: piers are provided with a link to the main walking axis -health track $\|$; beach area improvement is carried out, as well as attraction of geographically unconnected commerce. All structures are subject to the condition of preserving green spaces and must comply with the regulatory requirements for park buildings developed by specialists with the participation of the public specifically for this section of the park. The principles that determine the general direction of sustainable urban development are based on the ideology of solving global problems of modern Odessa, taking into account-balanced interaction of natural, socio-economic and technological subsystems during the development of Odessa about the coast without prejudice to future generations.

Key words: principles of sustainable urban development, coastal cities, Odessa slopes, Yubileiny park, landscape and recreation territory, park community centers, partnership program.

\section{СОВРЕМЕННОЕ СОСТОЯНИЕ И ПЕРСПЕКТИВЫ РАЗВИТИЯ ПРИБРЕЖНЫХ ТЕРРИТОРИЙ ОДЕССЫ}

Савицкая О. С., канд. арх., доцент, зав. кафедры градостроительства

e-mail: olgasavgrad@gmail.com; ORCID: orcid.org/0000-0003-0362-2502

Василенко А. Б., доктор архитектуры, профессор кафедры дизайна архитектурной среды e-mail: abvasilenko10@gmail.com; ORCID:0000-0002-8261-3104

Одесская государственная академия строительства и архитектурь

Аннотация: Статья является ответом на актуальную проблему развития и использования прибрежных территорий Одессы. В статье на основе анализа исторического, социального, градостроительного и экономического контекста аргументируется ландшафтно-рекреационное направление развития прибрежных территорий. Также определены принципы, основные стадии и методы формирования и содержания данной территории в масштабах от благоустройства до градостроительной роли в системе города. Выполнен анализ тенденций и проблем устойчивого развития городов. В создании «устойчивой» городской среды исключительно важна роль различных специалистов: градостроителей, архитекторов, экологов и «урбанистов» различных «городских» специальностей. Только методами комплексного 
подхода возможно создание полноценного, взаимосвязанного с природой, памятниками истории и культуры пространства. Принципы, определяющие генеральное направление устойчивого градостроительного развития, основаны на идеологии решения глобальных проблем современной Одессы, учѐте сбалансированного взаимодействия природной, социально-экономической и техногенной подсистем в ходе развития Одесского побережья без ущерба для будущих поколений.

Ключевые слова: принципы устойчивого развития городов, приморские города, одесские склоны, парк «Юбилейный», ландшафтно-рекреационная территория, парковые общественные центры, программа соучастия.

\section{СУЧАСНИЙ СТАН І ПЕРСПЕКТИВИ РОЗВИТКУ ПРИБЕРЕЖНИХ ТЕРИТОРІЙ ОДЕСИ}

Савицька О. С., канд. арх., доцент, зав. кафедри містобудування e-mail: olgasavgrad@gmail.com; ORCID: orcid.org/0000-0003-0362-2502

Василенко О. Б., доктор архітектури, професор кафедри дизайну архітектурного середовища e-mail: abvasilenko10@gmail.com; ORCID:0000-0002-8261-3104 Одеська державна академія будівництва та архітектури

Анотація: Стаття є відповіддю на актуальну проблему розвитку та використання прибережних територій Одеси. У статті на основі аналізу історичного, соціального, містобудівного та економічного контексту аргументується ландшафтно-рекреаційний напрям розвитку прибережних територій. Також визначені принципи, основні стадії та методи формування та змісту даної території в масштабах від благоустрою до містобудівної ролі в системі міста. Виконано аналіз тенденцій і проблем сталого розвитку міст. У створенні «стійкого» міського середовища виключно важлива роль різних фахівців: містобудівників, архітекторів, екологів і «урбаністів» різних «міських» спеціальностей. Тільки методами комплексного підходу можливе створення повноцінного, взаємопов'язаного з природою, пам'ятками історії та культури простору. Принципи, що визначають генеральний напрямок сталого містобудівного розвитку, засновані на ідеології вирішення глобальних проблем сучасної Одеси, обліку збалансованої взаємодії природної, соціально-економічної та техногенної підсистем в ході розвитку Одеського узбережжя без шкоди для майбутніх поколінь.

Ключові слова: принципи сталого розвитку міст, приморські міста, одеські схили, парк «Ювілейний», ландшафтно-рекреаційна територія, паркові громадські центри, програма співучасті.

Formulation of the problem. The current state and future development of the Odessa coast is the most acute problem of the city and requires serious comprehensive scientific research, as well as the development of principles and methods of urban landscape organization, the implementation of which will solve important practical problems.

Purpose of work: to determine the principles, main stages and methods of forming this territory on a scale from landscaping to urban development role in the city system.

Objectives: on the basis of the analysis of the historical, social, urban planning and economic context, to form a landscape and recreational direction for the development of the coastal territories of Odessa.

Many coastal cities have a complex coastal relief. Taking into account the features of construction on complex terrain is especially important. Studies on the formation of the functional planning structure of cities in specific regions are covered in the works of Krogius V. R. [10, 11], Yezhov V. I., Kushnirenko M. M. [9, 12], Ustenko T. V. [21], Shcherban V. K. [22], V. V. Sopilki [16], Zaretsky V. I. [7], Pilyukova N. V. [14] and others. The work analyzes the experience 
of developing complex terrain. Particular attention is paid to the formation of the planning structure of cities, the relationship of complex relief and development, examples of urban planning solutions on a complex relief are given. The methodological recommendations of Kilvanderom E. Ya. and Gagarkin A.G. cover the issues of engineering protection and development of geotechnically complex territories. The methods of construction on landslide plots are given. Features of the organization of resorts and recreation areas are considered in the works of Panchenko T. F. [13] and others. In the studies of Kushnirenko M. M. [12], the features of the formation of compositional relationships of the urban structure and landscape are considered. The organization of the architectural and spatial environment, taking into account visual perception, is devoted to the works of E. Belyaeva [2], V. V. Tovbych [20], A. V. Zakharov [8], A. G. Babenko [1]. Architectural solutions of coastal development, taking into account visual perception during movement and from fixed points, are considered in scientific articles by Talalaev V.V. [17], Ustenko T.V.

The main factor influencing the formation of coastal buildings in coastal cities is the sea. The presence in the architectural and natural urban ensemble of open sea space determines the features of the perception of the city's architecture. Among the factors that form the development of coastal areas are the features of visual perception of objects located on the coasts. Features of the architectural formation of embankments are disclosed in the works of Denisov M. F. [5], Kochnover F. G. and Rastorguev O.S.

In the dissertation, Erysheva E. A. [6], the principles of forming an architectural panorama in the conditions of a coastal city are revealed. The paper considers the features of the compositional and spatial structure of coastal cities, formulates a methodology for a comprehensive analysis of architectural panoramas. The practical significance of the work lies in the possibility of using the main research results in the architectural and urban planning practice of designing and developing coastal cities [4]. In the work of Glazyrin V. L. "The architectural and planning formation of public coastal centers in the structure of Odessa and its urban agglomeration", the urban planning problems of the Odessa agglomeration are analyzed, the principles are identified and methodological proposals for the formation of public coastal centers are presented. In the framework of the work, V. L. Glazyrin proposed experimental schemes and possible architectural and planning solutions for coastal community centers. Recently, there have been changes in the use and development of coastal areas of the coast of Odessa. Already now there are contradictions between theoretical proposals and the real practical situation (the functional purpose of the facilities under construction on the coast). Unfortunately, the changes that have occurred in the political situation and the legislative framework contribute to the chaotic and erratic development of the coast of Odessa.

The works of scientists have created a theoretical basis for scientific research in the field of architectural organization of coastal territories. At the present stage, only general provisions have been developed for the formation of the image of the city, its silhouette, architectural and planning organization of coastal zones. The formation of the architectural panorama of the coastal city, the identification of urban development features of the building, its functional coastal zoning and the interaction of the beach, park and upper residential areas require further study.

Cities play a paramount role in the economic, social, cultural, spiritual state, interaction and development of society. But at the same time, they have a devastating effect on the environment. The need to change the traditional urban development patterns has led to the concept of sustainable development. Increasing the sustainability of cities will not only positively affect their population, but will also significantly contribute to improving the well-being of people [1]. Global changes in urban development are a distinctive feature of the modern world. The high speed of urbanization processes has led to significant discrepancies between the needs, available resources and the intensity of their use. Time pushes many new challenges to the surface [2]. Existing ways of thinking cannot provide analysis, explain the course of events, suggest specific solutions. All this needs new forms of urban planning organization and new urban planning principles. There is a real need for a transition to an innovative development path. It is necessary to set promising innovative 
tasks, develop and implement innovative projects to ensure effective and integrated development of the city - a high-level habitat [2].

All cities have their own differences, which means that each city must find its own path to sustainable development. This also applies to Odessa, which is unique and unique in Europe, having such a long extension of the green coastal sea zone.

The concept of coastal development is unambiguously a landscape-recreational zone. This determines the maximum recreation, development, improvement of the natural complex; minimization and localization of urbanized areas; withdrawal from the zone of automobile transport; the organization of convenient, aesthetically and environmentally friendly communications of the city with the coast, taking into account all the visual points of disclosure, both on the sea and on the marine facade; organization of water public transport.

All these issues are resolved based on the features of historical development, the prevailing urban planning, architectural and cultural traditions of Odessa.

The vast coastal territory of Odessa requires a separate approach. . What is important is how this territory will develop over time, in the socio-economic, functional and political system of the city and country. Therefore, before dividing the project development process into stages, it is necessary to determine the dimensions within which the object will be studied and developed:

- Geographical and administrative location;

- Parameters;

- The social significance of the facility itself and surrounding areas;

- The economic system of relations of the object with the city;

- Range of functional content;

- A vector of time from studying the history of the formation of the Odessa slopes, their development to this day;

- Domestic and world experience.

Studies show that cottages, which had vast territories, mainly with park and garden architecture, occupied a significant part of the Odessa slopes. Arcadia has always stood out as a favorite place of Odessa residents, mainly because it was located in a beam and therefore had natural convenient access to the beach and the sea. The quality of these architectural structures can be seen on old postcards, photographs, archival drawings, documents collected and systematized for individual sections of the coast. These are mainly beautiful gazebos, rotundas, open galleries, a summer theater and much more. In the area of Arcadia and the Alexander Park (today the park named after T. G. Shevchenko), more capital structures were also concentrated in recreation areas. The buffet in the Alexander Park is architecturally unique and scaled to the place. The winter restaurant in Arcadia has survived to our time, but, unfortunately, it has turned from a dominant into an ordinary building, visually closed by local shops, of dubious appearance, unworthy of this place.

The layout and improvement of Otrada, the Alexander Park, were in no way inferior to the principles of organizing such parks as Versailles, Schönbrunn, Peterhof, of course, on a different scale and with its regional peculiarity, where the culture of organizing space and respect for the place was at a high level. We can see picturesque natural landscapes that are very much appreciated in large cities. As a rule, architects and designers created them artificially, so that the city dweller had the opportunity to communicate with nature and receive aesthetic pleasure, physical and psychological recovery.

The Soviet period made its adjustments, solving the problems arising before the city, in connection with the increase in the population. In the 60-70s of the XX century. shore protection work was carried out on most of the coast. But this did not change the functional purpose of this territory as a generally accessible green massif with the necessary service infrastructure, large-scale environment, with its own mistakes and regional peculiarities. Before the collapse of the Soviet Union, this territory had the status of the Yubileiny park.

Unfortunately, during the years of independence, the slopes suffered significant damage, and in some ways even irreparable. A haphazard, ill-conceived, sometimes barbaric approach to the 
development of this territory has led to its modern look, which, judging by various sociological surveys of the opinions of the inhabitants of Odessa, does not satisfy anyone. At the moment, it is a well-groomed, spontaneous and not high-quality landscaped area that does not have a decent view both from the sea and from the city. The exception is part of the embankment in the area of 16 st. The Big Fountain, which is landscaped by an investor who has mastered a piece of land on the upper plateau.

With a good location relative to the city, Odessa slopes are not balanced in function and in intensity of operation, which leads to their inefficient use and economic loss of the territory. The analysis revealed a complex of accumulated problems:

- administrative and political: the lack of a clear status of the territory and certain boundaries; the absence of persons responsible for the territory or a fuzzy definition of the duties and responsibilities of organizations; misuse of territories; lack of effective territory management;

- social and functional: partial violations of open access to the sea and park areas; irrational, unaesthetic and inadequate improvement; ineffective law enforcement system; criminogenic night scene; complete lack of navigation; inefficiency of connections between the public spaces of the slopes with the city public transport network and tourist routes; inferiority of the internal transport system, including marine;

- economic: loss-making for the main containing party - the city; lack of uniform rules for cooperation with entrepreneurs; risk of loss or improper reorganization of territories; the potential of this territory for the entire city was hardly revealed;

- environmental: the park violated environmental and sanitary conditions; the territory of the park is gradually losing the function of the ecological tread of the city;

- cultural: a limited range of cultural services provided; very weak interaction with the cultural organizations of the city; seasonality of existing services; lack of objects and spaces stimulating the self-organization of cultural events.

The city of Odessa belongs to the rapidly developing cities of Ukraine, with an actively developing (developing) territory. This factor carries both positive features (the city is enlarging and compacting) and negative ones (extensive and unbalanced use of territorial and natural resources). The existing park on the territory of Odessa slopes is unique for world practice, the natural environment within the city, which is a buffer and protective zone between the city and the sea ..

One of the options that allows you to breathe into the city a new streamlined direction of development of the Odessa coast is the decision to form city-axis (directions) of the city - sea. As a result, we get convenient communication city - park (slopes) - beach - sea. On the upper plateau, the possibility of forming urban ensembles of different functional purpose of the slope territory, their connection in the form of stairs, ramps, escalators and other ways of vertical communication between the upper and lower plateaus.

Along the greater part of the upper edge of the slopes, the upper boulevard is assumed, from which a sea panorama will open from the side of the city. Today this takes place in the area of the 12-13 station of the Big Fountain, where now we can observe such a view of the sea and really imagine it from other angles. The development of these areas will make it possible to uncover a sea view in the form of urban planning and architectural ensembles, which in the future will form an expressive facade of Odessa.

The submitted proposal on the structure of the park territory proposes to develop the existing network of pedestrian and transport links, in particular, to use the so-called -Health Trackll as a basis, which currently performs the main pedestrian-binding function along the coast. For communication with the city, vertical corridors have been identified, which are organized along existing descent to the sea and located in places of active communication. It is proposed to duplicate a horizontal route along the upper terrace of the park where possible, where this boulevard will be used both as a connection and as a place of public attraction.

It is also proposed to develop a bicycle and pedestrian equipment system for this network with the introduction of additional types of transport such as bicycles, treadmills, and official vehi- 
cles, in addition to pedestrian traffic, into the communications system. Qualified calculations of the entire system are also necessary, including the development of individual nodes without resorting to typological copying. Private road transport is closed to the shore, and visitors are brought in and out at the expense of domestic special vehicles. Territory maintenance by motor transport should be carried out according to the regime schedule.

The road network provides communication between park centers and sub - centers. In such places, different rules apply to the use of the park, where they should be dominated by entertainment and mass commercial services with maximum accessibility for visitors from the city. On the upper terrace car parking is organized. Park centers and sub centers are saturated with objects of year-round functioning, but at the same time, such objects are subject to the basic rules for preserving the territory of the park.

In the development of the existing prevailing park structure, it is planned to place places for visitors to relax, places for meetings, walks, physical education, and the connecting vector of the park as an environment for cultural and children's recreation with no barrier access.

All this is formed under the condition of: - complete conservation of green areas; point inclusion of improvement in the structure of the park; improvement of roads and trails (outdoor furniture, information support and navigation); the formation of places of various saturation and functionality; conservation of the -wildll park.

The network of engineering improvement develops exclusively along the roads, providing the necessary services (electricity, sewage, water supply) of the main highways and crowded places, with the use of autonomous energy supply systems, lighting of the -health routell when forming the safety axis.

All structures are subject to the condition of preserving green spaces and must comply with the regulatory requirements for park buildings developed by specialists with the participation of the public specifically for this section of the park.

It is planned to attract commercial structures corresponding to the format of a specific zone of the park. These are restaurant business, sports and entertainment clubs, temporary pavilions, rental services (non-motorized vehicles, beach and park portable furniture).

The coastal zone is decided in the format of a fully accessible shore: piers are provided with a link to the main walking axis -health trackl; beach area improvement is carried out, as well as attraction of geographically unconnected commerce.

The coastal zone retains the advantage of open beaches, in addition to this, an embankment boulevard with point service is organized. Beach amenities include changing rooms, showers, toilets, smoking areas, trash containers.

Possible formats for attracting investments are:

- maximum development of commercial service from the organization directly managing the park;

- development of programs for the one-time lease of small sections of the green zone of the park, without destroying and spoiling it, for events or the placement of commercial structures;

- Development of rental programs for plots in park centers and under centers;

- development of maintenance programs for engineering support (roads, water, sewage, electrics);

- development of cooperation programs with organizations involved in public events;

- development of programs to promote the development of a business park, favorably located to the park territory;

- inclusion in the urban development program of conditions for improvement and the maintenance of adjacent (or separate) zones of the park;

- sponsorship cooperation program;

- development of rental structures for non-motorized vehicles (bicycles, scooters, skateboards, rollers, boats, park and beach portable furniture, sports equipment, picnic sets, etc.);

- storage services; paid parking on the upper tier bordering the city; 
- a network of mobile kitchens, where the kitchen-restaurant itself is located in a park center or sub center, and there is a food delivery service or a customer delivery service to the restaurant throughout the park, as well as mobile kiosks (ice cream, drinks, fast food);

- controlled placement of advertisements;

- cultural and entertainment leisure (amusement park, rope town, climbing wall, diving center, etc.);

- organization of public events: thematic festivals and exhibitions, fairs, competitions, concerts, private and corporate events (weddings, birthdays, professional holidays).

Odessa slopes are part of the landscape - recreational territory of Odessa. The main subject fully interested in the development of this territory in the status of a park is the city itself. Based on this, the concept offers the following development strategy:

- Formation of a single organization engaged in the development of park and green areas of the city, interested exclusively in their development. Definition of the structure: administrative apparatus; service staff; system of cooperation with third-party enterprises; the formation of departments assigned to specific park units; determination of the need for the territorial location of departments in these places; development of a maintenance schedule for park units; mutually beneficial cooperation program: seasonal hired workers to serve visitors and the park; permanent staff; a system of cooperation with educational organizations (universities, schools and preschools) - attracting students to promote urban and park culture; system of cooperation with public organizations.

- The formation of public opinion both to support initiatives to preserve the park, as well as for creative events aimed at the exchange of views and wishes between citizens and designers.

Partnership program: promotion of park protection - involvement of political and public organizations, selection of specialists from the public; propaganda of complicity; calculation of social benefits for partners; organization of an advertising company; propaganda of urban culture (park culture); involvement in the promotion of educational institutions; development of a volunteer work program in parks.

- Project development: all-round complicity; development of a project implementation strategy taking into account maximum savings and minimization of financial costs; accurate legal definition of all areas of the park; formation of rules for using park areas; formation of rules for the use of green spaces; determination of the stages of development of the park; development of the project of the first stage of implementation; the formation of the social environment of the park.

To ensure safety, the conditions of a well-viewed area must be observed:

- illumination of the main road of the -health routell;

- the presence of people (attracting people through the expansion of services, cultural events, the formation of a "friendly" environment);

- patrolling and video control of unpopular accessible territories;

- regime access to unprotected territories (preventing the placement of a point of attraction far from the controlled territory);

- control of violations of public law and security.

To ensure year-round relevance, it is necessary to provide a system of measures to ensure the attractiveness of any place in the park. Provide the necessary amenities for the season.

Conclusions. As a result of a study of the historical and modern development of the city of Odessa, problems and prerequisites for the development of coastal territories are identified. The necessity of restoring planning and spatial and spatial connections between the city territory and the coastal zone (taking into account the scale of the city), creating an expressive marine facade in the framework of the general strategic interests of the city and its residents, provided that valuable natural resources are preserved, is determined. The proposed priority steps that should become the starting point and political basis for the successful implementation of the development strategy of the "Odessa slopes" are: 
- impose a moratorium on the construction, design and issuance of permits and approvals of any objects in a given territory;

- conduct a comprehensive inventory and analysis of the existing state of development and land ownership in this territory.

Based on the comprehensive study, it is necessary to prepare a scientifically based program-task for further real design of the park territory.

\section{LITERATURE}

1. Бабенко А. Г. Пространственнные ориентиры и их функции в городской застройке: автореф. канд. арх.: 18.00.01/ Моск.арх.ин-т. - М., 1986. - 22 с.

2. Беляева Е. Л. Архитектурно-пространственная среда города как объект зрительного восприятия. - М.: Стройиздат, 1977. - 127 с.

3. Бунин А. М. История градостроительного исскуства. Том 1: Рабовладельческий строй. Феодализм. Капитализм. - М.: Стройиздат. - 1953 с.

4. Глазирін В. Л. Архітектурно-розпланувальне формування громадських приморських центрів в структурі Одеси та іï міські агломерації: автореф. дис. канд. арх.: 18.00.04/ КГТУСиА. - К., 1998. - 13 с.

5. Денисов М. В. Архитектура городских набережных (Интеграция ландшафтов и сооружений): автореф. дис. док-ра арх.: 18.00.04/ МАРХИ. - М., 1988. - 46 с.

6. Еришева Е. А. Формирование архитектурной панорамы крупного приморского города (на примере г. Владивосток): автореф. дис. канд. арх.: 18.00.01. / Моск.архит.ин-т. - М., 1992. $-24 \mathrm{c}$.

7. Зарецкий В. Я. Районная планировка курортных местностей. (Опыт СССР) Обзор. - М: Центр науч.-технич. информации по гражданскому строительству и архитектуре, 1970.

$-54 \mathrm{c}$.

8. Захаров А. В. Визуальное восприятие как фактор формирования градостроительной композиции: автореф. дис. канд. арх.:18.00.01/ Моск. арх. ин-т. - М., 1986. - 24 с.

9. Кушниренко М. М. Планировка и застройка городов в условиях прибрежного ландшафта: Учебное пособие для иностранных студентов. - К., 2003. - 172 с.

10. Крогиус В. Р. Актуальные вопросы решения планировочной структуры городов в условиях сложного рельефа // Формирование структуры и архитектурного облика городов: сборник статей. - К., 1972. - С. 39-43.

11. Крогиус В. Р. Город и рельеф. - М.: Стройиздат, 1979. - 124 с.

12. Кушниренко М. М. К вопросу о градостроительном значении приморских территорий // Региональные проблемы архитектуры и градостроительства: сборник научных трудов.

- Odessa: Город мастеров, 1999. - Выпуск 2. - С. 17-19.

13. Панченко Т.Ф. Планировочная организация общественных центров в курортнорекреакционных зонах: Обзор информ. / ТСНТИ по гражданскому строительству и архитектуре. - М., 1982. -33 c.

14. Пилюкова Н. В. Градостроительное освоение неудобных территорий (на примере причерноморских городов): автореф. дис. канд. арх.: 18.00.04/МАРХИ. - М., 1978. - 22 с.

15. Семенов В. Т. Устойчивое развитие мегаполисов. Урбанистические аспекты: монография / В. Т. Семенов, Н. Штомпель, Харьк. нац. ин-т гор. хоз-ва им. А. Н. Бекетова. - Х: ХНИГХ, 2014. - 339 с.

16. Сопилка В. В. Особенности композиции жилой застройки в условиях сложного рельефа // Формирование структуры и архитектурного облика городов: сборник статей. - К., 1972. - C. $46-57$.

17. Талалаев В. В. Особенности архитектурно-пространственной композиции прибрежной жилой застройки с учетом зрительного восприятия ее при // Планировка и застройка городов: сб. науч. трудов. - К., 1975. - С. 69-76. 


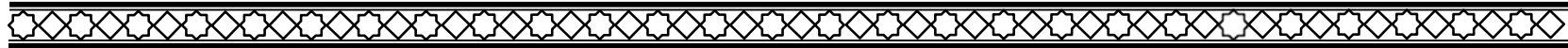

18. Проблемы урбанизации на рубеже веков. - Смоленск: Ойкимена, 2002. - 328 с.

19. Тимофеенко В.И. Одесса: Архитектурно-исторический очерк. - К.: Будівельник, 1984. $160 \mathrm{c}$.

20. Товбыч В.В. Интерактивное графическое моделирование архитектурной среды с учетом особенностей ее візуального: дис. ...канд. техн. наук: 05/01/01/ Киев. инж.-стр. ин-т. - К., 1986. -206 c.

21. Устенко Т. В. Принципы формирования архитектурно-планировочной структуры жилых прибрежных районов // Формирование структуры и архитектурного облика: сборник статей. - K., 1972. - С. 33-39.

22. Щербан В. К. Ландшафт и архитектура города. - К.: Будівельник, 1987. - 87 с.

УДК 711.4 .01

doi: 10.31650/2519-4208-2020-20-27-35

\section{ОСОБЛИВОСТІ ФОРМУВАННЯ МОРСЬКОГО ФАСАДУ МІСТА ОДЕСИ}

Панченко Т. Ф., професор, доктор архітектури, завідувач кафедри ландшафтної архітектури.

Київський національний університет будівництва і архітектури e-mail: panchenko.knuba@gmail.com,ORCID:0000-0001-6341-230X

Сторожук С. С., кандидат архітектури, доцент кафедри містобудування.

Одеська державна академія будівництва та архітектури

e-mail:mesvet@ukr.net, ORCID:0000-0001-8390-7190

Анотація: У статті розглянуті проблеми формування морського фасаду міста Одеси. Було вивчено світовий досвід формування морських фасадів найбільш яскравих приморських міст. Однією з особливостей сприйняття міста $\epsilon$ його панорама і силует, де панорама - вид на територію міста, а силует - вертикальне контурне позначення забудови міста. Було проаналізовано прибережні території міста Одеси з точки зору силуету міста 3 боку моря. В результаті видно, що силует одноманітний і нудний, єдиною його особливістю є портові споруди, а візуальне сприйняття Одеси з боку моря нічим не примітне і не може конкурувати з іншими приморськими містами світу, що вимагає звернути особливу увагу на іï прибережні території. Для визначення основних принципів формування морського фасаду міста Одеси були розглянуті наукові роботи одеських вчених, а також варіанти експериментального проектування.

Ключові слова: силует, панорама міста, морський фасад, композиція міста, узбережжя.

\section{ОСОБЕННОСТИ ФОРМИРОВАНИЯ МОРСКОГО ФАСАДА ГОРОДА ОДЕССЫ}

Панченко Т. Ф., профессор, доктор архитектуры, заведующая кафедрой ландшафтной архитектуры.

Киевский национальный университет строительства и архитектуры

e-mail: panchenko.knuba@gmail.com, ORCID: 0000-0001-6341-230X

Сторожук С. С., кандидат архитектуры, доцент кафедры градостроительства.

Одесская государственная академия строительства и архитектуры

e-mail:mesvet@ukr.net, ORCID:0000-0001-8390-7190

Аннотация: В статье рассмотрены проблемы формирования морского фасада города Одессы. Был изучен мировой опыт формирования морских фасадов наиболее ярких приморских городов. Одной из особенностей восприятия города является его панорама и силуэт, где па- 